\title{
The Relationship of Fuhrman Nuclear Grade, Tumor Stage and Sarcomatoid Differentiation with Survival in Renal Cell Carcinomas
}

\author{
Ebru Taştekin'1, Fulya Öz Puyan'1, Mustafa Kaplan², Burcu Tokuç², Vuslat Yürüt-Çaloğlu4, Filiz Özyılımaz', Ufuk Usta', A. Kemal Kutlu \\ ${ }^{1}$ Department of Pathology, Faculty of Medicine, Trakya University, Edirne, Turkey \\ ${ }^{2}$ Department of Urology, Faculty of Medicine, Trakya University, Edirne, Turkey \\ ${ }^{3}$ Department of Public Health, Faculty of Medicine, Trakya University, Edirne, Turkey \\ ${ }^{4}$ Department of Radiation Oncology, Faculty of Medicine, Trakya University, Edirne, Turkey
}

\section{ABSTRACT}

Objective: Renal cell carcinoma derived from tubular epithelium is one of the malignant tumors of the kidney. We have investigated the histological features, pathological stage, nuclear grade and sarcomatoid differentiation of these tumors.

Material and Methods: Histological slides from seventy-eight nephrectomy specimens diagnosed as renal cell carcinoma between 2000 and 2008 were reevaluated according to the 2004 World Health Organization classification system of kidney tumors. Reclassified cases were collected in five groups and were scored for Fuhrman nuclear grading, stage, sarcomatoid differentiation and survival rate.

Results: In our study, cases with high nuclear grade, advanced stage and sarcomatoid differentiation revealed poor survival rates ( $p<0.05)$. In conclusion, the correlation between prognostic histopathological parameters and survival rates was consistent with literature findings.

Conclusion: Fuhrman nuclear grading, stage and sarcomatoid differentiation are important parameters and are related factors in survival when investigating renal cell carcinomas. Fuhrman nuclear grading must be evaluated correctly and the highest grade should be reported. Although there aren't enough studies about sarcomatoid differentiation, its presence significantly decreases survival rates. It is very important to state histopathological parameters including sarcomatoid differentiation precisely on the pathology report.

Key Words: Renal cell carcinoma, prognosis, angiogenesis

Received: 11.10 .2010

Accepted: 28.01.2011

\section{Introduction}

Renal cell carcinoma (RCC) is an important health problem in adults, which constitutes $80-85 \%$ of renal tumors and $2 \%$ of all malignancies. The incidence is increasing in the world and 100.000 with RCC patients die per year (1).

Metastasis is frequent because the symptoms develop quite late and treatment may be started in the late stages. Approximately $1 / 3$ of the patients have metastases and five year survival rate is under $5 \%$ in this group of patients (1).

Many factors have an impact on survival duration in RCC. All of these factors affect the course of the disease as dependent (tumor related) and independent prognostic factors. Tumor related factors are known as parameters which are determined by tumor stage (tumor size, local tumor spread, adrenal gland, large vessels, lymphatic nodes involved, far metastasis), histologic subtype, nuclear grade, sarcomatoid differentiation and histological tumor necrosis (2).

There are various clinical trials which focus on factors affecting life duration and determination of survival duration in RCC. The aim of our study is to investigate the relation between life duration and tumor related factors which can affect survival.

\section{Material and Methods}

The surgical pathology reports of all patients who underwent nephrectomy for RCC between 1998 and 2008 in our hospital were reviewed. Histological slides from seventy eight nephrectomy specimens with RCC were re-evaluated retrospectively to determine a consistent set of pathologic features. If required, new sections from the blocks of nephrectomy specimens were cut. All histological sections were stained with Hematoxylin and Eosin. The histologic subtype, Fuhrman Nuclear Grading (FNG), stage and sarcomatoid differentiation (SD) of all patients were reviewed by two pathologists who were blind to the clinical features and outcome of the patients. The size of each neoplasm and macroscopic renal vein involvement and other macroscopical findings were extracted from the pathology reports. The pathological findings (histologic subtype, stage, FNG and sarcomatoid differentiation) were re-classified according to new evaluation results.

For classification of renal tumors, the World Health Organization (WHO) 2004 classification was used (3).

Nuclear grade was determined using the criteria proposed by Fuhrman et al. (4). FNG-1 tumors are composed of 
cells with small (approximately $10 \mu \mathrm{m}$ ), round, uniform nuclei and inconspicuous or absent nucleoli; FNG-2 tumor cells have larger (approximately $15 \mu \mathrm{m}$ ) nuclei with irregular outlines and nucleoli that are visible under high-power (400X) microscopy; FNG-3 tumor cells have even larger nuclei (approximately 20 $\mu \mathrm{m})$ with obvious irregular outlines and prominent nucleoli even under low-power (100X) microscopy; and FNG-4 tumors exhibit features similar to those of FNG-3 tumors but also have bizarre, often multilobed nuclei and heavy chromatin clumps.

The tumors were staged according to the 2002 TNM classification system using the AJCC stage grouping; tumor 4 $\mathrm{cm}$ or less in greatest dimension, limited to the kidney; Stage $1 \mathrm{a}$, tumor more than $4 \mathrm{~cm}$ but not more than $7 \mathrm{~cm}$ in greatest dimension, limited to the kidney; stage $1 \mathrm{~b}$, tumor more than $7 \mathrm{~cm}$ in greatest dimension, limited to the kidney stage 2 , tumor extends into major veins or invades adrenal glands or perinephric tissue but not beyond Gerato's fascia stage 3, tumor invades beyond Gerato's fascia; stage 4 (5). Stage 1a and $1 \mathrm{~b}$ were unified into a single group in order to make statistical comparisons. Sarcomatoid differentiation was assessed on histologic sections and was graded into two categories, present or absent.
Survival information was obtained from the patient followup unit of the university or by phone from the patients themselves or relatives. The local ethics committee approved the study design (No.64/2008-10/18). This study was supported by the Trakya university scientific research projects (TUBAP, Project number 108/08).

Statistical analysis was performed using the Statistica 7.0 (License number: 31N6YUCV38) software package. The data were analyzed using descriptive analysis and the survival calculations were illustrated with Kaplan-Meier Curves. The power of the results of survival analysis was assessed according to sarcomatoid differentation and 3 years survival rates were found to be $88.3 \%$ and $58.3 \%$ for cases with and withouut sarcomatoid differentation, respectively. The power was 0.98 if " $n$ " value was 78 and $\alpha=0.05$.

\section{Results}

According to the final evaluation, 48 (61.5\%) of the patients had clear cell RCC. The final diagnosis of other patients were as follows; 10 (12.8\%) papillary RCC, 10 (12.8\%) unclassified type RCC, 5 (6.4\%) chromophobe RCC and 5 (6.4\%) multilocule

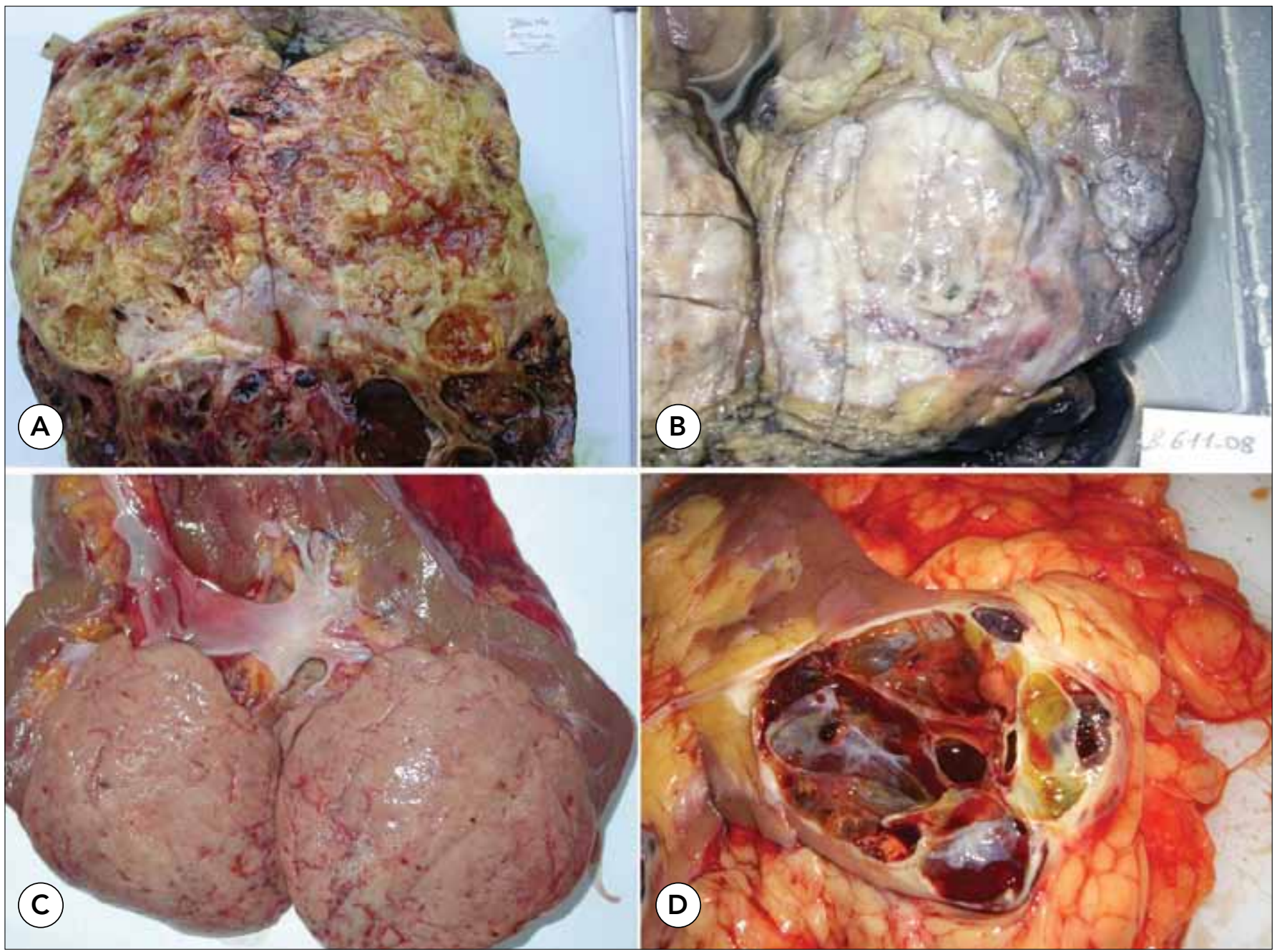

Figure 1. The macroscopic appearances of histological subtypes in renal cell carcinoma patients. A: Clear cell renal cell carcinoma; B: Papillary renal cell carcinoma; C: Chromophobe renal cell carcinoma; D: Multilocule-cystic renal cell carcinoma 


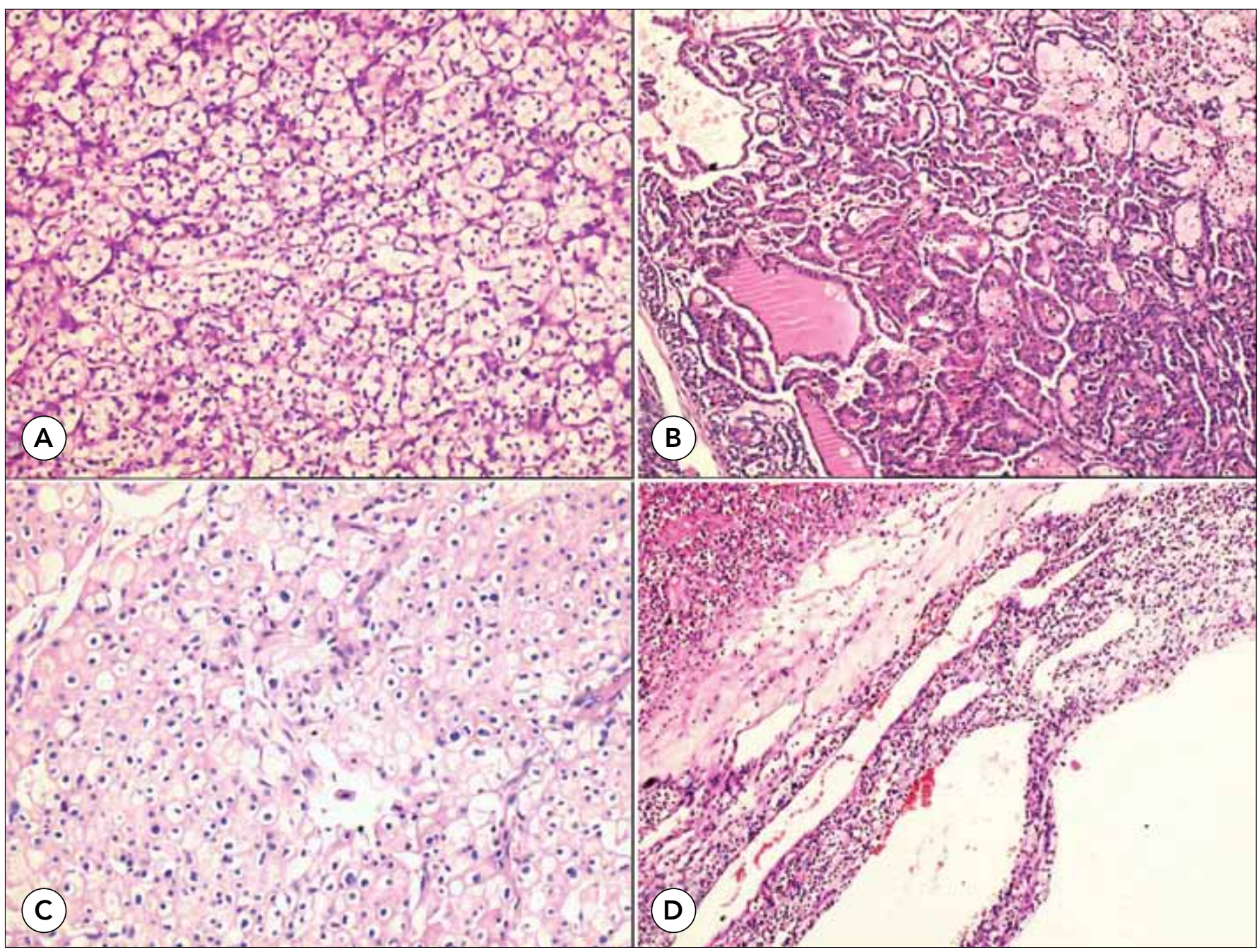

Figure 2. The microscopic appearances of histological subtypes in renal cell carcinoma patients. A: Clear cell renal cell carcinoma (HEX100), B: Papillary renal cell carcinoma (HEX50), C: Chromophobe renal cell carcinoma (HEX100), D: Multilocule-cystic renal cell carcinoma (HEX1.25)

Table 1. Gender-histological type crosstabulation

\begin{tabular}{|c|c|c|c|c|c|c|c|c|}
\hline & & & & & ological & & & \\
\hline & & & CC-RCC & P-RCC & $\mathrm{C}-\mathrm{RCC}$ & MLC-RCC & Un-RCC & Total \\
\hline Gender & male & Count & 30 & 9 & 2 & 2 & 7 & 50 \\
\hline & & $\%$ within gender & $60.0 \%$ & $18.0 \%$ & $4.0 \%$ & $4.0 \%$ & $14.0 \%$ & $100.0 \%$ \\
\hline & & $\%$ within histological type & $62.5 \%$ & $90.0 \%$ & $40.0 \%$ & $40.0 \%$ & $70.0 \%$ & $64.1 \%$ \\
\hline & female & Count & 18 & 1 & 3 & 3 & 3 & 28 \\
\hline & & $\%$ within gender & $64.3 \%$ & $3.6 \%$ & $10.7 \%$ & $10.7 \%$ & $10.7 \%$ & $100.0 \%$ \\
\hline & & $\%$ within histological type & $37.5 \%$ & $10.0 \%$ & $60.0 \%$ & $60.0 \%$ & $30.0 \%$ & $35.9 \%$ \\
\hline
\end{tabular}

cystic RCC (MLC-RCC). Macroscopic and microscopic appearances of histological subtypes can be seen in Figures 1, 2.

The study group consisted of 50 (64.1\%) patients for male and $28(35.9 \%)$ for female (Table 1). Age interval changes were between 26 and 80 . The mean ages were $60.25 \pm 10.20$ in patients with clear cell RCC; $64.10 \pm 10.00$ in papillary RCC, $54.00 \pm 17.00$ in chromophobe RCC, $40.40 \pm 14.20$ MLC-RCC, $58.80 \pm 13.70$ in unclassified RCC (Table 2). Tumor localization was right kidney in $40(51.3 \%)$ of the patients and left kidney in 38 (48.7\%). 
Table 2. Age distribution of patients

\begin{tabular}{|lcccc|}
\hline & N & Mean age \pm SD & Minimum & Maximum \\
\hline CC-RCC & 48 & $60.25 \pm 10.24$ & 37.00 & 80.00 \\
P-RCC & 10 & $64.10 \pm 10.00$ & 45.00 & 78.00 \\
C-RCC & 5 & $54.00 \pm 17.04$ & 26.00 & 72.00 \\
MLC-RCC & 5 & $40.40 \pm 14.18$ & 24.00 & 53.00 \\
Un-RCC & 10 & $58.90 \pm 13.69$ & 36.00 & 80.00 \\
Total & 78 & $58.89 \pm 12.31$ & 24.00 & 80.00 \\
\hline $\begin{array}{l}\text { CC-RCC: Clear cell renal cell carcinoma; P-RCC: Papillary renal cell carcinoma; C-RCC: Chromophobe renal cell carcinoma; MLC-RCC: Multilocule cystic renal } \\
\text { cell carcinoma; Un-RCC: Unclassified renal cell carcinoma } \\
\text { p= } 0.004 \text { (Kruskal Wallis analysis of variance) }\end{array}$ & &
\end{tabular}

Survival evaluation revealed a general survival rate of $78.21 \%$ and a mean survival duration of 86.6 months $(86.59 \pm 4.8)$ in RCC (Figure 3). Among histological subtype groups, the survival rate was $81.25 \%$ and mean survival duration 88.14 months in clear cell RCC. The same values were $70 \%$ and 62.03 months in papillary RCC, respectively. All the patients with chromophbe RCC and MLC-RCC were alive. Survival rate was $50 \%$ and mean survival duration was 55.2 months in unclassified RCC. The longest survival duration and highest survival rates were in patients with clear cell RCC when chromophobe RCC and MLC-RCC patients were excluded. Both parameters were low in unclassified RCC patients. However, no significant difference in terms of survival duration was found among histological subtypes on statistical evaluation (Figure 4).

The distribution of FNG, stage, size and SD properties of the patients in histological subtype groups were shown in Table 3. Fourteen of the patients (17.9\%) were in FNG-1; 32 (41.0\%) in FNG-2; 20 (25.6\%) in FNG-3; 12 (14.1\%) in FNG-4. While the survival rates were $78.57 \%$ and $93.75 \%$ in FNG-1 and FNG-2, survival rates were $65 \%$ in FNG-3 and $58.33 \%$ in FNG-4, respectively. The comparison of survival rates in FNGs revealed that survival rates and survival durations decreased as FNG grades increased. The difference of these parameters among FNG groups were found to be statistically significant $(p=0.021)$ (Figure 5).

Of all the patients, 31 were in stage $1(39.75 \%) ; 17$ in stage $2(21.9 \%), 26(33.33 \%)$ in stage 3, $4(5.12 \%)$ in stage 4 . When stage groups were compared with the survival rates and mean survival durations, higher stage correlates with lower values of survival rates and mean survival durations. There was a statistically significant difference among pathological stages and survival duration and rates $(p=0.001)$ (Figure 6).

When evaluating SD, 11 of 78 RCC patients (14\%) exhibited this finding and $8(72.7 \%)$ of these patients had clear cell RCC, while 3 (27.3\%) had unclassified RCC (Figure 7). SD was observed more frequently in large size tumors as a remarkable finding. The diameter of these tumors was greater than $7 \mathrm{~cm}$ in $81.8 \%$ of the patients. When the relationship was evaluated between SD and survival, it was observed that RCC patients with SD had a survival rate of $54.55 \%$ and survival duration of 28.18 months, while patients without SD had a survival rate of

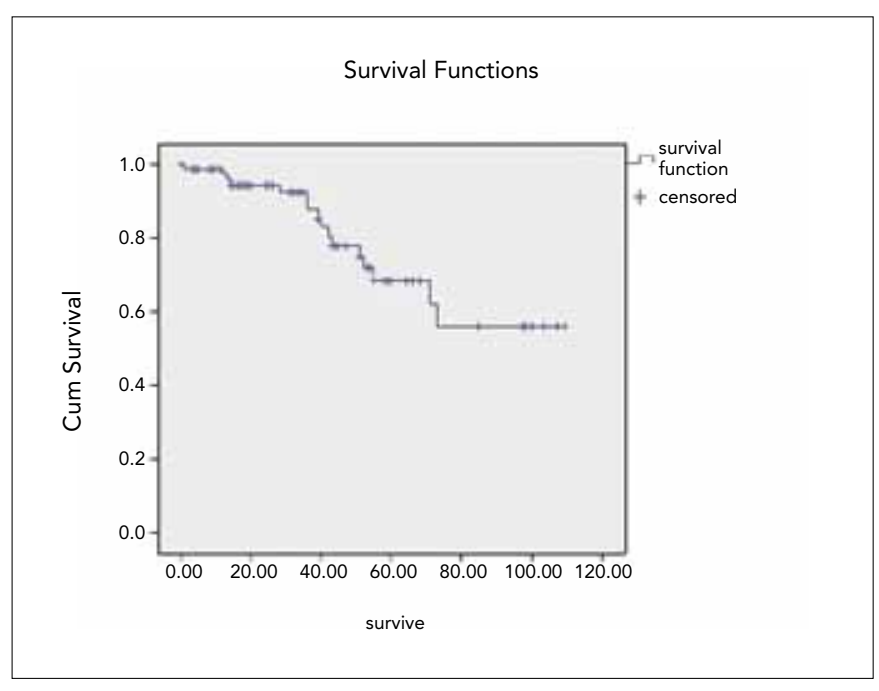

Figure 3. The survival rates of the renal cell carcinoma patients

Cum Survival: Cumulative survive, Survive: Life duration (month)

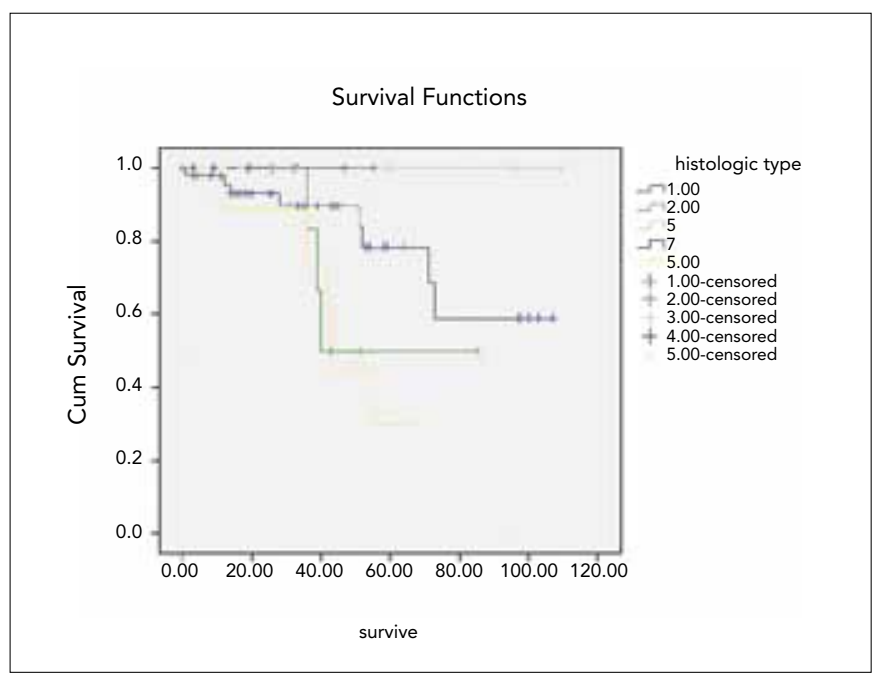

Figure 4. The survival rates of the histological types in renal cell carcinoma patients

Cum Survival: Cumulative survive, Survive: Life duration (month), Histological Type: 1: Clear cell renal cell carcinoma; 2: Papillary renal cell carcinoma; 3: Chromophobe renal cell carcinoma; 4: Multilocule-cystic renal cell carcinoma; 5: Unclassified renal cell carcinoma 
Table 3. The distribution of Fuhrman Nuclear Grading (FNG), stage, size and Sarcomatoid differantiation (SD) properties of the patients in histological subtypes

\begin{tabular}{|c|c|c|c|c|c|c|c|c|c|c|c|c|c|}
\hline \multirow[t]{2}{*}{$\begin{array}{l}\text { Histological } \\
\text { Subtype }\end{array}$} & \multicolumn{4}{|c|}{$\begin{array}{l}\text { FNG } \\
(n, \%)\end{array}$} & \multicolumn{4}{|c|}{$\begin{array}{l}\text { Stage } \\
(n, \%)\end{array}$} & \multicolumn{3}{|c|}{$\begin{array}{c}\text { Size } \\
(n, \%)\end{array}$} & \multicolumn{2}{|c|}{$\begin{array}{c}\text { Sarcomatoid } \\
\text { Differantiation } \\
(n, \%)\end{array}$} \\
\hline & 1 & 2 & 3 & 4 & 1 & 2 & 3 & 4 & $<4 \mathrm{~cm}$ & $\geq 4-7 \mathrm{~cm}$ & $>7 \mathrm{~cm}$ & $(+)$ & $(-)$ \\
\hline $\begin{array}{l}\text { CC- RCC } \\
(n=48)\end{array}$ & $\begin{array}{c}7 \\
14.6 \%\end{array}$ & $\begin{array}{c}21 \\
43.8 \%\end{array}$ & $\begin{array}{c}11 \\
22.9 \%\end{array}$ & $\begin{array}{c}9 \\
18.8 \%\end{array}$ & $\begin{array}{c}19 \\
39.6 \%\end{array}$ & $\begin{array}{c}9 \\
18.8 \%\end{array}$ & $\begin{array}{c}16 \\
33.3 \%\end{array}$ & $\begin{array}{c}4 \\
8.3 \%\end{array}$ & $\begin{array}{c}10 \\
20.8 \%\end{array}$ & $\begin{array}{c}18 \\
37.5 \%\end{array}$ & $\begin{array}{c}20 \\
41.7 \%\end{array}$ & $\begin{array}{c}40 \\
83.3 \%\end{array}$ & $\begin{array}{c}8 \\
16.7 \%\end{array}$ \\
\hline $\begin{array}{l}\text { P-RCC } \\
(n=10)\end{array}$ & $\begin{array}{c}2 \\
20 \%\end{array}$ & $\begin{array}{c}5 \\
50 \%\end{array}$ & $\begin{array}{c}3 \\
30 \%\end{array}$ & $\begin{array}{c}0 \\
0 \%\end{array}$ & $\begin{array}{c}4 \\
40 \%\end{array}$ & $\begin{array}{c}3 \\
30 \%\end{array}$ & $\begin{array}{c}3 \\
30 \%\end{array}$ & $\begin{array}{c}0 \\
0 \%\end{array}$ & $\begin{array}{c}2 \\
20 \%\end{array}$ & $\begin{array}{c}3 \\
30 \%\end{array}$ & $\begin{array}{c}5 \\
50 \%\end{array}$ & $\begin{array}{c}10 \\
100 \%\end{array}$ & $\begin{array}{c}0 \\
0 \%\end{array}$ \\
\hline $\begin{array}{l}\text { C-RCC } \\
(n=5)\end{array}$ & $\begin{array}{c}1 \\
20 \%\end{array}$ & $\begin{array}{c}4 \\
80 \%\end{array}$ & $\begin{array}{c}0 \\
0 \%\end{array}$ & $\begin{array}{c}0 \\
0 \%\end{array}$ & $\begin{array}{c}2 \\
40 \%\end{array}$ & $\begin{array}{c}2 \\
40 \%\end{array}$ & $\begin{array}{c}1 \\
20 \%\end{array}$ & $\begin{array}{c}0 \\
0 \%\end{array}$ & $\begin{array}{c}0 \\
0 \%\end{array}$ & $\begin{array}{c}2 \\
40 \%\end{array}$ & $\begin{array}{c}3 \\
60 \%\end{array}$ & $\begin{array}{c}5 \\
100 \%\end{array}$ & $\begin{array}{c}0 \\
0 \%\end{array}$ \\
\hline $\begin{array}{l}\text { MLC-RCC } \\
(n=5)\end{array}$ & $\begin{array}{c}4 \\
80 \%\end{array}$ & $\begin{array}{c}1 \\
20 \%\end{array}$ & $\begin{array}{c}0 \\
0 \%\end{array}$ & $\begin{array}{c}0 \\
0 \%\end{array}$ & $\begin{array}{c}4 \\
80 \%\end{array}$ & $\begin{array}{c}1 \\
20 \%\end{array}$ & $\begin{array}{c}0 \\
0 \%\end{array}$ & $\begin{array}{c}0 \\
0 \%\end{array}$ & $\begin{array}{c}1 \\
20 \%\end{array}$ & $\begin{array}{c}3 \\
60 \%\end{array}$ & $\begin{array}{c}1 \\
20 \%\end{array}$ & $\begin{array}{c}5 \\
100 \%\end{array}$ & $\begin{array}{c}0 \\
0 \%\end{array}$ \\
\hline $\begin{array}{l}\text { Un-RCC } \\
(n=10)\end{array}$ & $\begin{array}{c}0 \\
0 \%\end{array}$ & $\begin{array}{c}1 \\
10 \%\end{array}$ & $\begin{array}{c}6 \\
60 \%\end{array}$ & $\begin{array}{c}3 \\
30 \%\end{array}$ & $\begin{array}{c}2 \\
20 \%\end{array}$ & $\begin{array}{c}2 \\
20 \%\end{array}$ & $\begin{array}{c}6 \\
40 \%\end{array}$ & $\begin{array}{c}0 \\
0 \%\end{array}$ & $\begin{array}{c}2 \\
20 \%\end{array}$ & $\begin{array}{c}3 \\
30 \%\end{array}$ & $\begin{array}{c}5 \\
50 \%\end{array}$ & $\begin{array}{c}7 \\
70 \%\end{array}$ & $\begin{array}{c}3 \\
30 \%\end{array}$ \\
\hline $\begin{array}{l}\text { Total } \\
(n=78)\end{array}$ & 14 & 32 & 20 & 12 & 31 & 17 & 26 & 4 & 15 & 29 & 34 & 67 & 11 \\
\hline
\end{tabular}

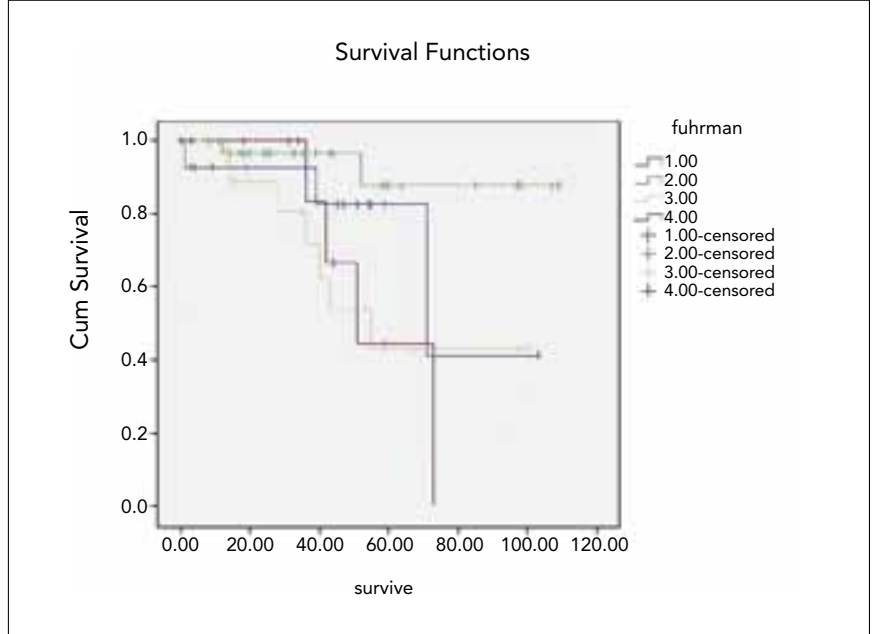

Figure 5. The survival rates of the Fuhrman Nuclear Grading groups in renal cell carcinoma patients

Cum Survival: Cumulative survive Survive: Life duration (month).

1: Fuhrmann Nuclear Grade-1; 2: Fuhrmann Nuclear Grade-2; 3: Fuhrmann Nuclear Grade-3; 4: Fuhrmann Nuclear Grade-4

$82.09 \%$ and survival duration of 90.5 months. This difference was statistically significant $(p=0.018)$ (Figure 8$)$.

\section{Discussion}

As renal tumors cause late symptoms due to their retroperitoneal localizations, they are generally diagnosed in the advanced stage. Early diagnosis is sometimes possible when local symptoms and paraneoplastic signs appear earlier $(6,7)$. Although a surgical approach is possible, metastasis is frequent and prognosis is poor in advanced stages. Thus, optimal determination of prognostic factors is vitally important in the treatment of renal tumors and survival of the patients.

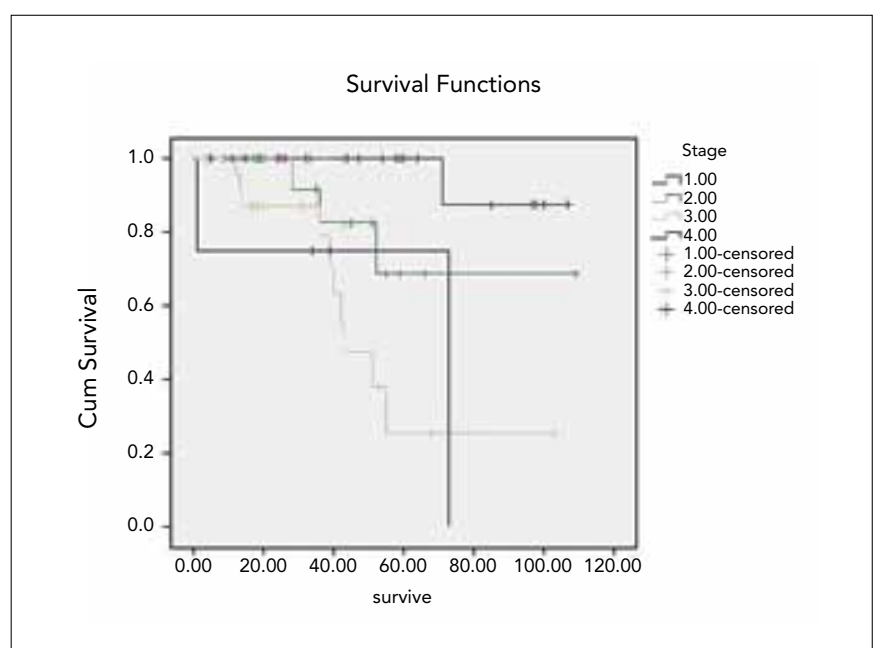

Figure 6. The survival rates of the stage groups in renal cell carcinoma patients

Cum Survival: Cumulative survive, Survive: Life duration (month).

1: Stage 1, 2: Stage 2, 3: Stage 3, 4: Stage 4

It has been reported that the five year survival rates of the patients with RCC is $30-60 \%$. The longest follow up duration among our patients was 10 years and the shortest was 1 year, with a general survival rate of $78.21 \%$ and mean survival duration of 86.6 months. However, it has been reported that there are important differences among histological subtypes. The 5-year disease-specific survival for chromophobe RCC, papillary RCC, clear cell RCC, and unclassified RCC was 100\%, $86 \%$, $76 \%$, and $24 \%$, respectively (8). Cheville et al. (9) and Patard et al. (10) showed that prognosis is the best in the chromophobe type and worst in the clear cell type. Similarly, we found that the best prognosis appeared in patients with chromophobe RCC and MLC-RCC. However, in contrast to this study, the 


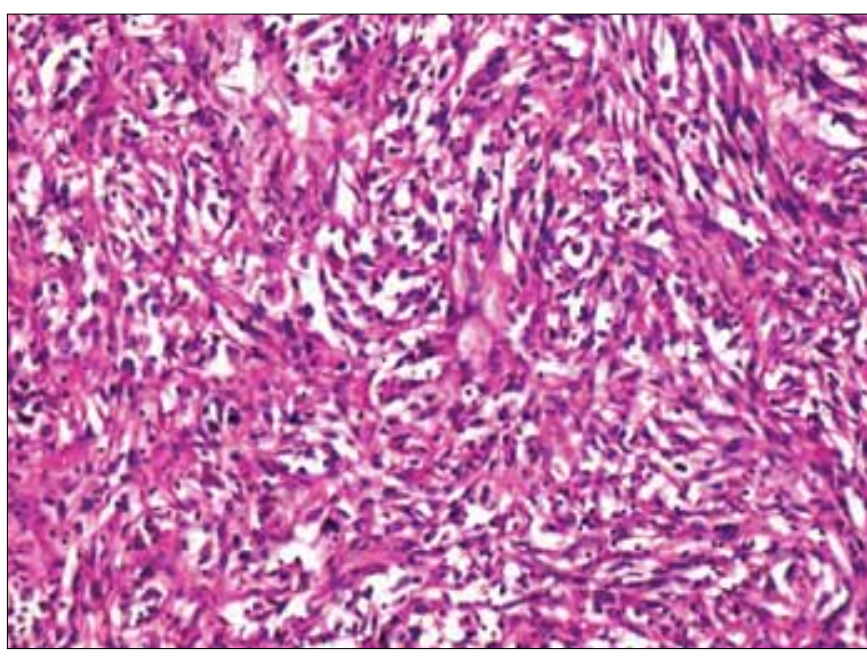

Figure 7. A sample of sarcomatoid differentiation in a renal cell carcinoma patient (HEX100)

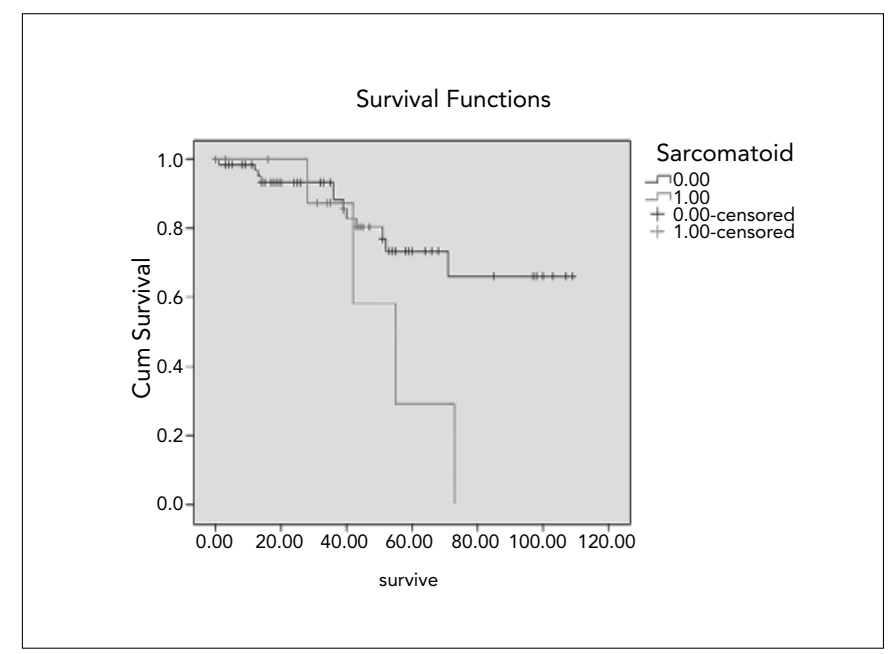

Figure 8. The survival rates of the sarcomatoid differentiation in renal cell carcinoma patients

Cum Survival: Cumulative survive, Survive: Life duration (month). Sarcomatoid differantiation: 0: Absent, 1: Present

longest survival duration and highest survival rate were in patients with clear cell RCC following chromophobe RCC and MLC-RCC. The shortest survival duration and the lowest survival rate were found in patients with unclassified RCC. As a large number of patients had clear cell RCC and the number of patients were low in other subtype groups, no statistically significant difference could be obtained between survival rate and histological subtypes.

The most important predictor of prognosis in RCC patients is accepted to be the histopathological stage (7). Survival rates decrease with increasing stage $(11,12)$. Recent studies revealed that five year survival is $90-100 \%$ in stage 1 tumors, $75-90 \%$ in stage $2,60-70 \%$ in stage 3 and $15-30 \%$ in stage 4 (10). General survival rates in our study were found to be $96.7 \%, 82.35 \%, 57.69 \%$ and $29.75 \%$, respectively; these findings are parallel to the findings of the former studies.

Evaluation criteria used in tumor grading is subjective and evaluation discordance is possible for all grading systems. De- spite this, nuclear grading is the most important prognostic parameter for almost all malignant tumors. While differentiation (morphologic and/or functional) and anaplasia are generally used for grading of tumors, only nucleus and nucleolus features (size and morphology) are evaluated in RCC (12). The FNG system is currently the most frequent evaluation method used in RCC (13). In this system, four groups are constituted in terms of nucleus contour, size and nucleolus intensity. According to Delahunt et al. (13), the subjectivity of the criteria and variation in tissue fixing methods can cause interpretation differences in the FNG system. Nucleoli are not visible in poorly fixed tissues, thus tumors might have been classified as low grade. Besides, the same investigators pointed to the FNG system as being insignificant in subtypes other than clear cell RCC and stated that this system should not be used in papillary and chromophobe RCC. They claim that the FNG distribution is unstable in chromophobe RCC and this leads to discordance in grading among the observers. In Delahunt and al.'s study, eighty-seven cases of chromophobe renal cell carcinoma were investigated. Authors emphasized that the fact that all the 8 dead chromophobe RCC patients had FNG-2, supports this opinion (13-17). According to our observations, tissue fixing is a misleading factor that complicates the evaluation. Sometimes, nucleus structure in chromophobe RCC can cause higher interpretation degrees of FNG. All of the chromophobe RCC were FNG-1 and FNG-2 in our study and no FNG-3 and FNG-4 patient existed. In addition to the recommendation of Delahunt et al. (13), we advise mutual evaluation of FNG by two different pathologists for an objective evaluation and to decrease error probability. We also recommend that careful screening of tumor areas with the worst nuclear grading should be the focus of the evaluation. Although the number of patients with chromophobe RCC is insufficient in our study, it is not practical to use the FNG system on chromophobe RCC cases. Kus et al. (18) found that the survival rate decreased as FNG increased. Gelb et al., (19) performed their study on 82 patients with grade $1 \mathrm{RCC}$ and showed that nuclear grading and tumor size are independent factors for survival. Similarly, the survival rate and duration decreased significantly as FND increased in our study.

In Goldstein et al.'s study (20), while FNG-1 and FNG2 showed similar prognostic features, FNG-3 and FNG-4 showed the same similarity among these. The survival rates of our patients are in concordance with their results. Although it was not possible to perform a statistical analysis due to the insufficient number of patients in some groups, the advanced stages with FNG increase and diameters being greater than 7 $\mathrm{cm}$ in $91.7 \%$ of FNG-4 tumors are striking findings.

$\mathrm{SD}$ is an important finding that accompanies many tumors $(21,22)$. It can be shown in many types of RCC. SD is much more evaluated in FNG-4 group tumors. De Peralta-Venturina et al. (22) investigated 101 cases with SD and reported that SD was observed in $8 \%$ of clear cell RCC, $9 \%$ of chromophobe RCC, and $11 \%$ of unclassified RCC. Our cases showed SD in $16.7 \%$ of clear cell RCC, and $30 \%$ of unclassified-RCC. This sign was absent in chromophobe RCC. In De Peralta-Venturina et al.'s (22) studies, while $63 \%$ of patients with SD were in stage 3 and $25 \%$ in stage 4 , mean survival duration was 19 
months. Similarly, in our study, $50 \%$ of cases were in stage $3,50 \%$ in stage 4 and the mean survival duration was 28.8 months. Five of 11 cases with SD are deceased. The presence of SD decreases survival rate and duration. These groups of tumors have a markedly worse prognosis and most of them die in one year (21). Therefore, SD should be sought and their presence should be indicated in pathological reports.

Some factors limited our statistical analysis and a better discussion of our data. Although a ten year period of experience was evaluated, the low number of patients in some groups was an important limitation.

There are important markers in determining the prognosis of renal tumors showing quite late symptoms and being diagnosed in the late advanced stage. We investigated the presence of the most important parameters which should be used to determine the survival durations and rates in these cases. Despite low numbers of patients in some groups, we have achieved significant results associated with survival.

According to the statistical analysis, the results of our study showed important relations of histological subtype, FNG, stage and SD with survival. We think that the FNG classification should be performed by two different pathologists for enhancing the accuracy of the evaluation, and the worst grade should be reported after scanning various areas. While there are many studies investigating the relation among FNG, tumor stage and survival, the number of studies about the relation of SD and survival is limited. Yet, according to our results, the presence of SD decreases the survival rates significantly. We therefore consider that accurate evaluation and clear definition of these parameters by pathologists affect the quality of clinical approach and, consequently, survival and quality of life.

\section{Conflict of Interest}

No conflict of interest was declared by the authors.

\section{References}

1. Chow WH, Devesa SS, Warren JL, Fraumeni JF Jr. Rising incidence of renal cell cancer in the United States. JAMA 1999;281:162831. [CrossRef]

2. Lohse CM, Cheville JC. A review of prognostic pathologic features and algorithms for patients treated surgically for renal cell carcinoma. Clin Lab Med 2005;25:433-64. [CrossRef]

3. Eble JN, Togashi K, Pisani P. Renal cell carcinoma. In: Eble JN, Sauter G, Epstein JI, Sesterhenn IA (Eds.) Pathology and genetics of tumors of the urinary system and male genital organs. World Health organization classification of tumors. Lyon: IARC Press; 2004.p.10-14
4. Fuhrman SA, Lasky LC, Limas C. Prognostic significance of morphologic parameters in renal cell carcinoma. Am J Surg Pathol 1982;6:655-63. [CrossRef]

5. Green F, Page D, Fleming L. AJCC cancer staging manual. 6th ed. New York: Springer; 2002.

6. Kim HL, Belldegrun AS, Freitas DG, Bui MH, Han KR, Dorey FJ, et al. Paraneoplastic signs and symptoms of renal cell carcinoma: implications for prognosis. J Urol Nov 2003;170:1742-6. [CrossRef]

7. Amin MB, Amin MB, Tamboli P, Javidan J, Stricker H, de-Peralta Venturina $M$, et al. Prognostic impact of histologic subtyping of adult renal epithelial neoplasms: an experience of 405 cases. Am J Surg Pathol 2002;26:281-91. [CrossRef]

8. Jayson M, Sanders H. Increased incidence of serendipitously discovered renal cell carcinoma. Urology 1998;51:203-5. [CrossRef]

9. Cheville JC, Lohse CM, Zincke H, Weaver AL, Blute ML. Comparisons of outcome and prognostic features among histologic subtypes of renal cell carcinoma. Am J Surg Pathol 2003;27:61224. [CrossRef]

10. Patard JJ, Leray E, Rioux-Leclercq N, Cindolo L, Ficarra V, Zisman A, et al. Prognostic value of histologic subtypes in renal cell carcinoma: a multicenter experience. J Clin Oncol 2005;23:2763-71. [CrossRef]

11. Robson CJ, Churchill BM, Anderson W. The results of radical nephrectomy for renal cell carcinoma. J Urol 1969;101:297-301.

12. Lang $\mathrm{H}$, Jacqmin D. Prognostic factors in renal cell carcinoma. EAU Update Series 2003;1:215-9. [CrossRef]

13. Delahunt B, Sika-Paotonu D, Bethwaite PB, McCredie MR, Martignoni G, Eble JN, et al. Fuhrman grading is not appropriate for chromophobe renal cell carcinoma. Am J Surg Pathol 2007;31:957-60. [CrossRef]

14. Giulliani L, Giberti C, Martorana G, Rovida S. Radical extensive surgery for renal cell carcinoma: long term results and prognostic factors. J Urol 1990;143:468-74.

15. Skinner DG, Colvin RB, Vermillion CD, Pfister RC, Leadbetter WF Diagnosis and management of renal cell carcinoma. A clinical and pathologic study of 309 cases. Cancer 1971;28:1165-77. [CrossRef]

16. Kontak JA, Campbell SC. Prognostic factors in renal cell carcinoma. Urol Clin North Am 2003;30:467-80. [CrossRef]

17. Sika-Paotonu D, Bethwaite PB, McCredie MR, William Jordan T, Delahunt B. Nucleolar grade but not Fuhrman grade is applicable to papillary renal cell carcinoma. Am J Surg Pathol 2006;30:10916. [CrossRef]

18. Kus E, Yıldız K, Dillioğlogil O. Correlation between Fuhrman Nuclear grade and stage with survival in Renal Cell Carcinoma. Turk J Path 2009;25:71-7. [CrossRef]

19. Gelb AB, Shibuya RB, Weiss LM, Medeiros LJ. Stage I renal cell carcinoma. A clinicopathologic study of 82 cases. Am J Surg Pathol 1993;17:275-86. [Cross-Ref]

20. Goldstein NS. Grading of renal cell carcinoma. Urol Clin North Am 1999;26:637-42. [CrossRef]

21. Ro JY, Ayala AG, Sella A, Samuels ML, Swanson DA. Sarcomatoid renal cell carcinoma: clinicopathologic study of 42 cases. Cancer 1987;59:516-26. [CrossRef]

22. De Peralta-Venturina $M$, Moch $H$, Amin $M$, Tamboli $P$, Hailemariam S, Mihatsch $M$, et al. Sarcomatoid differentiation in renal cell carcinoma: a study of 101 cases. Am J Surg Pathol 2001;25:27584. [CrossRef] 